\title{
Criterion of the Nationality. Case Study of the National Museum in Warsaw (Department of Contemporary Prints and Drawings)
}

What are the most important principles when creating art collections? What do people responsible for the contents of the museum's storages aim for? Are those rules and criteria continuous, repeating every era and political system, or do they change depending on the given circumstances? Do the criterion of the nationality of the artist carries any weight? Is it possible that just as the capital is regaining nationality in difficult historical moments, the artist's nationality, especially when we experience air, hunger, war, or a pandemic, is gaining importance? Or is it only a matter of systematics, a classificatory criterion? Is it important that Andy Warhol was of Czech descent? Or Mother Teresa - Albanian?

The scope of my ponding covers primarily art museums established in the XIX century, alternatively the ones from the beginning of the last century and specifically the Department of Contemporary Prints and Drawings in the National Museum in Warsaw. The nowadays museums opened in the last quarter of the previous century and later are usually on a mission to create precisely defined collections. Their tasks consist mostly of collecting with a thesis, building a space for a dialogue or an ideological dispute, and illustrating specific phenomena and changes taking place in the society. The Museum of Modern Art in Warsaw defines its mission in these words: "We want to be useful. We treat art as a means of communication, of discovering and understanding the world. A piece of art in our Museum isn't just meant for contemplation. It helps us learn social responsibility, dialogue, critical thinking, and influencing reality". Moreover, the Museum's mission clearly emphasizes that it is a glocal institution: "The Museum is closely 
tied with Warsaw, its history and inhabitants, all the while actively taking part in artistic life in Poland and abroad" (artmuseum.pl 2020). To sum up, this is not a museum templum meant for contemplation and learning, but a museum forum - a museum of ideologically engaged art, a museum of dialogue between yesterday and today, between the old and the new.

I am confident that the so-called artistic value should play the primary role in the policy of creating art collections. Furthermore, I believe it should always remain the main responsibility of the guardian of museum's collections. In retrospect, it turns out even the collections gathered with the ideologies in mind sometimes have an unexpected future.

The permanent exhibitions of the olden museums dating back to the XVIII century usually try to focus on one field; in case of the museums of art that would mean expounding on the traditional history of art. Natural history museums, for example the Geological Museum of the Polish Geological Institute in Warsaw, depicts the history of the Earth. The authors of the current exhibition admit that there are more modern classification systems of the organic world than the one they present, however, it is the old positivist one that is more legible to the average recipient. This obviously applies only to the systematics and not the individual discoveries; for example the authors mention the acknowledgement of the recent addition of conodonts to vertebrates in their exhibition (geoportal.pgi.gov.pl 2019).The issue of where the particular rock had been found and whether it was in Poland will always be in place, however, when it comes to the history of the Earth it does not matter.

The historical museums present the history; for example the POLIN Museum in Warsaw covers the history of Jews in Poland. This particular history is delineated using personal stories told most of the time by individuals and documented with art and everyday items. Exhibitions in these museums are considered to be historical and not problematizing the theme of presentation. The criterion of the nationality of the artist in this case is simple as the authors of the artwork are mostly of Jewish origin. Following the same argument, the art museums present the history of art in the chronological order and the divisions into schools or, in case of modern art, into artistic movements. Sometimes schools would tie in with the criterion of the nationality as modern art usually mixes both national and foreign art.

In the modern museology the museum's aim is not to just teach history or history of art. Museum it is based on peculiar ideology and tries to convey certain message, always has its own story to tell and it is not just a silent room full of reticent objects (Zając 2005: 370). If one sees museums as a place for interpretations rather than contemplations (Szczerski 2005: 341), it is important to remember that the criterion of nationality can influence the policy of collecting. Now, the question arises of whether it is relevant to the traditional museums. 
The art museums, especially the older ones, are consistently accumulating their collections using the outdated category of artistic value. When it comes to modern art it does not refer just to the aesthetics. Even generally, it does not most of the times, because in the XX century there are not many works of art considered "beautiful" in the same sense as before. The modern history of art claims that aesthetic value is not objective and therefore it is possible to question it. The museum gives worth to certain pieces.

Alan Goldman in his text Aesthetic Value writes that artistic value lies first in "the challenge and richness of the perceptual, affective, and cognitive experience" of the works of art.

Symbolic and expressive density combines here with sensuous feel. From the subjective side all one's perceptual, cognitive, and affective capacities can be engaged in apprehending these relations, even if one's grasp of them is imperfect or only implicit. These different facets of appreciation are not only engaged simultaneously, but are also often indissolubly united as when formal relations amount musical tones or painted shapes are experienced as felt tensions and resolutions and perhaps as higher-order or some ordinary emotions as well (Goldman 1995: $150)$.

In practice, the determinants of the artistic value are mostly innovation, quaintness and the sincerity of the author. The engagement also plays a role; it is not, however, a necessary condition. It is also rarely the viewers' reception. At least in theory, traditional museums are not looking for non-artistic values in collecting policy. That being said, museums should not purchase artworks just because of the author's nationally.

What about the reality of how it was before and it is today? Unfortunately, especially for the last half of the century, it has been really political. After the end of World War II Poland found itself in the orbit of influence of the Soviet Union and was separated from Western Europe by so-called "the Iron Curtain". The Berlin Wall was built in 1961; it was a literal border between the two worlds impassable to neither side under the threat of death. The concept of "Rotten West" was coined by the regime press and it was supposed to depict the antinomy of the two societies living on both sides of the curtain: the healthy, developing, socialist one and the rotten, consumerist, capitalist one. Like many other saying's characteristic for the newspeak of that time, "Rotten West" was used in an ironic sense.

The contemporary division into two worlds meant that museums were treated as combat tools and instruments of power by both sides. The criterion of nationality served the contemporary politics which then determined our collections of foreign art. Naturally, that was not the first time this criterion was used. Throughout the interwar period, Polish artists looked for a national style while referring to folk art, either highlander or Slavic. However, at that time it was a matter of the newly regained Polish state coming into existence on the international arena after 123 years of partitions. The examples of the success of the Polish pavilion at 
the Paris exhibition in 1925, or the general intellection of the Universal National Exhibition in Poznan in 1929 and the exhibitions about the contemporary Polish art and its achievements, showcase that this was a necessary and effective action. Were the collections created at the time politically entangled? By all means. It was not, however, analyzed as thoroughly as it is today and it was not the subject of scientific research; the museology did not exist in the current form either.

The collections of The Department of Contemporary Prints and Drawings from the National Museum of Warsaw were sectioned off from the Polish Art collection in 1958. Even though in most cases the modern art repertory is random, its creation was contingent on the politics. The political aspect of the foreign art collections of most of the olden art museums is undeniable. The works of art that got to The Cabinet were mostly by artists from the communist bloc.

The counterweight for measures that could not be revolted was a conscious and open comportment of some of the contemporary curators. There is no doubt that they had to have a tacit consent of the management. It consisted of paying the tributes which meant creating Soviet art exhibitions, taking socialist realistic prints in without dispute, the aftermath of the National Art Exhibitions in Zachęta. In return, some of the curators were able to secretly obtain works of art from artists in exile. This kind of silent consent for the contemporary art collection at the National Museum in Warsaw to be - doesn't this sound familiar? - the space of dialogue was then given by the director of the Museum, i.e. Stanisław Lorentz (1899-1991), who in 1945-1951 fronted the National Directorate of Museums and Monuments. He prominently contributed to the expansion of the collection of the Warsaw establishment. What is more, he was aware that every good piece of art from every historical period is worth the attention, hence our repertory in Poland includes the only collection of graphics and ceramic plates by Pablo Picasso (Manicka 2017: 42-46).

If the contemporary communist authorities in Poland had not kept Lorentz's passport, ${ }^{1}$ we would probably also have pictures Picasso wanted to give us as at that time he considered himself a communist (Bibrowski 1979: 57). Thanks to Lorentz, we were able to purchase works of emigrant artists such as Felix Topolski (1907-1989), who was Tadeusz Pruszkowski's student and emigrated from Poland before the World War II. At that time, he lived in the Great Britain and was known for his reportage drawings. His career started when he illustrated the silver jubilee of King George V. Then he was a war cartoonist commissioned by Polish and British governments. Due to Lorentz we were also able to support a Lithuanian artist by purchasing his works, i.e. Stasys Eidrigievicius (born in 1949), who settled in Poland although he did not get the permanent residence permit until

1 In the communist countries keeping passports has been a common practice in this time; there were private and official passports and both had to be kept not at home but at the special passport office. Anyone who wanted to travel abroad had to ask for permission. Very often the passports were stored due to the political reasons. 
1980. During that time, it was also possible to buy works of Polish artists from the collectors in the West. Here one can mention the purchases of Konstanty Brandel's $(1880-1970)^{2}$ or Tadeusz Makowski's work (1882-1932)3. On the contemporary inventory cards there is a funny annotation in the view of today's ease in traveling: "the purchase of Tadeusz Rudnicki from Paris".

If the subject-matter (political connection) was legitimate, the curators tried to ensure the artwork had other qualities, for example a good composition, an intriguing colour scheme or a rare technique. However, that was not always possible. Obviously, among Soviet artists there were noteworthy individuals with works of art with aesthetical value as in was in case of Aleksiej Krawczenko (1889-1940) (Kulpińska 2013: 223-233). Doctor Irena Jakimowicz (1922-1999), the first curator of the Cabinet, used to carry out these kinds of activities.

However, it does not change the fact that for the circa 37,000 objects in the National Museum in Warsaw's collection, the one of modern foreign art counts up to 2,457 objects and the one of foreign drawings -693 objects, which is only approximately $8,5 \%$ of the whole.

At some point the collection started to include works of artists almost only from Eastern Europe and the far East. This means they came from countries that after the World War II were influenced by the Soviet Union. When talking about far East, I mean People's Republic of China and Vietnam, but not North Korea. Mexico, which around that time manifested its sympathy for communism, is also included in that list. Strangely, Italy isn't included in the group which after the World War II sympathized with the communists. The majority of our collection of the Italian graphics comes from the period after the breakthrough. In 1961 the collection of Mexican prints, the revolutionary woodcuts, were legalized and exhibited in the National Museum in 1949.

The Hindu art collection was started due to personal connections of the Cabinet's curator. In 1960 the Cabinet received a gift from the Japanese UNESCO committee which included a fair collection of Japanese prints from that time period. The political aim was probably to promote Japan not as an imperialistic empire defeated by an atomic bomb, but as a new democratic country open to the world and to communist bloc (the latter term, although it was officially used by the rulers of most Eastern European residents, had an ironic connotation).The Central Office of Art Exhibitions provided information that Chinese art was probably a travelling exhibition which ended up in the Museum. In 1964 we were gifted Israeli art by the Warsaw Embassy of Israel. In 1970 the Romanian Embassy gave us the artwork of Romanian artists. The last one was the "Rotten West". Around that period of time the art magazine Alte und Moderne Kunst published the origi-

2 A half Young Poland and a half contemporary artist, a graphic artist, a visionary and a landscape artist.

A painter from the Ecole d'Paris, painted in the spirit of naive realism and then Cubism, the author of paintings such as Children's Band (1922) or Jazz (1929). 
nal prints of Viennese artists which became a part of our collection. The collection was constantly enlarged, for instance with purchases from Verlag der Kunst in Dresden, the gift from Dresden's Kupferstichkabinett and from the Museum of Fine Arts in Budapest. This leads us to the breakthrough in 1966. That was the year when the first Print Biennale in Cracow took place. Finally, the foreign art collection becomes, at least partly, conscious and non-political. The International Print Biennale received prints from all over the world. Since the presence of the artists was not compulsory, the art would come in by post as more people could take part without the political authorities as well as the artistic institutions affiliation. Suddenly curators were able to take responsibility for their collections and treat them as the source of the living water. After 1966 the forced gifts and purchases were still coming though. However, for the first time in post-war history it became possible to pick the contents of the collections without ideological motives and gain full responsibility so the next generations could benefit from the collections and chose whatever was right for them.

All of the political decisions made about the contents of the collections with so many artists of different nationalities were unfair and harmful. In theory, traditional museums assume that their collections should be a kind of repository, a reservoir of life-giving juices and a source of living water for future generations. This rule had been broken way too many times as the contemporary policymakers did not feel responsible for the collections of the museum or for profit for future generations. They were building monuments of their power and ideologies without caring for aesthetic values of the art: the art, that was the testimony of the people living on those lands; people with certain beliefs and rituals. The traditional method of creating collections focuses on the aesthetics rather than ideology. That method proves to be working even if not always fully successfully.

For years I have been observing how the Cabinet's collections had been used in various ways and by various institutions, different than the ones that chose to use the Museum's collections during the last half of the century. Mostly one can observe how western museums fascinated with totalitarianism used the collections in perverse ways. One of the funniest examples was a great career of a small, inconspicuous etching by Halina Chrostowska (1929-1990)4; Cowhand and Spotted. It presents a picture of caring, chubby cowman taking care of a calving cow named Spotted. In the fifties this kind of images were supposed to convince society that only socialism cares about livestock; in the capitalist system the cowman would most likely just abandon his calving cow and probably go to sleep.

Our collection of social realism was admired in the Scandinavian countries. The collection of Chinese drawings interested British collectors in China because of the old-established tradition of studying and trading it long before the birth of People's Republic of China. The collection of Hungarian art took part in the exhi-

A graphic designer, after the poisoning with acid vapors and the damaging of the nerves in the hands caused by reagents, she had to abandon the graphic). 
bition of the polish print organized by the author of this text. A similar thing happened with our collection of Mexican art, our prints were a pendant for Andrzej Wróblewski's (1927-1957). ${ }^{5}$ Last year the Cultural Centre in Poznan organized an exhibition of Mexican prints as Frida Kahlo's students' artwork was found among our collections.

Even though the prints were supposed to showcase the primacy of socialist countries' art over the "Rotten West" one they turned out to have a different outcome. Some recipients found the depictions of the ideologies which were discrepant to the ones that put these works of art in our repertories. A gruesome example is the Chinese art. Collectors and enthusiasts of Robert van Gulik ${ }^{6}$ did not have the ability to pursue their interests in People's Republic of China as after the war he became an ambassador in Japan and Korea. Our drawings held appeal of British scholars on one of the academic conferences in Pekin (CIHA conference in 2016) and this resulted in them making their way into the international database devoted to Chinese art.

I say without doubt that the criterion of the nationality of the artist is relatively articulate; it is not a part of some ideology, rather just the current politics. The rule of the museum's collection as the source of living water is above any ideologies or politics. The most important responsibility of the collections' creators is making sure that the works of art are at a high level, have an artistic and aesthetic value, and not just support some kind of ideology. It is rather surprising but also very encouraging.

\section{Bibliography}

Bakos K., Manicka A.

2009 Dialog czarno na bialym. Grafika polska i wegierska 1918-1939/ Parbeszed Fekete-Feherben. Lengyel es magyar grafika 1918-1939/ Dialogue in black and white 19181939, transl. A. Bata-Bocian, Warsaw-Budapest.

Bibrowski M.

1979 Picasso and Congress in: Picasso in Poland, Kraków, p. 25-79.

Goldman Alan H.

1995 Aesthetic Value, Colorado.

Grzybal W., Ziółkowska M.

2014 Unikanie stanów pośrednich/ Avoiding Intermediary States, Warsaw. Kordjak J.

2009 Andrzej Wróblewski, Warsaw.

5 An artist whose paintings due to the fascination with his art in recent years began to intensively travel around Europe after World War II, sometimes arousing interesting reflections of the local curators.

6 1910-1967; diplomat, sinologist, author of the detective stories. 
Kulpińska K.

2013 „Czarna kreska na białym tle” - drzeworyt radziecki w polskiej krytyce artystycznej lat 30. XX w. i jego oddziaływanie na grafike polska in: Sztuka Europy Wschodniej/ Искусство Восточной Европь/ Art of Eastern Europe 2, Toruń, p. 223-233.

Manicka A.

2017 Kolekcja dziel Pabla Picassa w zbiorach Muzeum Narodowego w Warszawie/ Imago Multitudninis. The Collection of Works by Pablo Picasso at the National Museum in Warsaw in: Wizerunek Wielokrotny/ A multiple Image, [exh. cat.] Muzeum Lubelskie/ Lublin Museum, Lublin, p. 42-46.

Prignitz-Poda $\mathrm{H}$.

2017 Frida Kahlo i Diego Rivera. Polski Kontekst, Poznań.

Szczerski A.

2005 Kontekst, edukacja, publiczność in: M. Popczyk (ed.), Muzeum sztuki. Antologia, Kraków, p. 335-344.

Zając M.

2005 Nowa muzeologia, lub jak spojrzeć w oczy Meduzie in: M. Popczyk (ed.), Muzeum sztuki. Antologia, Kraków, p. 369-378.

Wróblewska D., Wierzchowska W., Mansfeld J.

2006 Grafika i pamięć. Rok 1966 największa przygoda polskiej grafiki, Kraków.

Internet sources:

https://artmuseum.pl/pl/muzeum/o-nas/misja-muzeum (access: 16.06.2020).

http://geoportal.pgi.gov.pl/kolekcje/slownik/systematyka (access: 2.10.2019). 